\title{
Home Environment and Self-Esteem: Comparative Study among Delinquent and Normal Boys
}

\author{
Deena. K. Varghese ${ }^{1 *}$, Dr. Sukanya. B. Menon ${ }^{2}$
}

\section{ABSTRACT}

Juvenile delinquency is one of the prevalent issues of modern society. The purpose of this study was to compare the family environment and self esteem of delinquent and normal boys. Sample comprised of 30 delinquent and 30 normal boys. Their age ranging from 11-15 years. The data was gathered by using Home environment inventory (Dr. Misra S K) and Rosenberg self-esteem scale (Rosenberg, 1965).Home environment inventory was used to measure the psycho-social climate of home as perceived by children. By using t-test, it was found that there is significant difference between home environment of delinquents and normal boys in the following dimensions-control, protectiveness, punishment, conformity, social isolation, reward, deprivation of privileges, nurturance and rejection. It was also found that there is significance difference between self-esteem of delinquents and normal boys.

Keywords: Juvenile delinquency, Home environment and self- esteem.

Juvenile delinquency is one of the major issues of the modern society. The delinquent juvenile is defined in section 2 of juvenile justice act 1986 as "A juvenile who has been found to have committed an offence. As per the act, juvenile means a boy less than 16 years of age and a girl less than 18 years of age.”

Many researchers found that family plays as an important etiological factor behind delinquency. Different family variables have been studied to better understand the etiology of delinquency. Parental control is the most important factor that is reflected in studies. Many studies suggest that lack of parent control foster delinquency. Emotional bonding has the capacity to reduce the negative effects of punishment (Aufserr, Jekielek \& Brown, 2006). Martens (1992) and Barber (1996) reported that close bonds with parents and emotional ties within the family among its members reduce the likelihood that juveniles will become delinquent. Self esteem is another

\footnotetext{
${ }^{1}$ Msc. Student, Christ University, Bangalore, India

${ }^{2}$ Asst. Professor, Prajyothi Nikethan College, Pudukad, India

*Responding Author

(C) 2016 D Varghese, S Menon; licensee IJIP. This is an Open Access Research distributed under the terms of the Creative Commons Attribution License (http://creativecommons.org/licenses/by/2.0), which permits unrestricted use, distribution, and reproduction in any Medium, provided the original work is properly cited.
} 
factor that influences antisocial behaviour. Low self esteem may lead to association with deviant peers and sometimes delinquency leads to low self esteem (Kelley, 1978).

From the above mentioned studies, it is evident that home environment and self esteem play an important role in the development of delinquent behaviours among adolescents. Hence, this research aimed to identify the differences in family environment and self-esteem of delinquent and normal boys

\section{METHOD}

\section{Sample:}

The total sample size was 60, divided into two groups: 30 juvenile delinquents and normal boys. Random sampling method was used. Information regarding 30 male juvenile delinquents was taken from Observation Home for Boys and Juvenile justice court, Thrissur. They had criminal record like shop lifting, Quarrelling, Property destruction and theft etc. And 30 normal boys were taken from Boys government higher secondary school, Kodungallur. The age range of both the sample was between 11 to 15 years.

\section{Tools:}

\section{Home environment inventory (Dr.Karuna Shankar Misra)}

Home environment inventory was developed by Dr.Karuna Shankar Misra. Home environment inventory is an instrument designed to measure the psycho social climate of home as perceived by children. It provides a measure of the quality and quantity of the cognitive, emotional and social support that has been available to the child within in the home.HEI has 100 items belonging to ten dimensions of home environment. The ten dimensions are as follows: control, protectiveness, punishment, conformity, and social isolation, and reward, deprivation of privileges, nurturance, rejection and permissiveness.

\section{Scoring the responses to HEI items:}

There are five cells against every item of the inventory. Each cell indicates the occurrence of a particular behaviour. The five cells belong to five responses namely: mostly, often, sometimes, least and never. Assign 4 marks to mostly, 3 marks to often, 2 marks to sometimes, 1 mark to least, and 0 marks to never response. The Home environment inventory has been found to possess content validity and split half reliability.

\section{Rosenberg Self-esteem scale:}

The Rosenberg self esteem scale was developed by Dr. Morris Rosenberg is a widely used self esteem measure in social science research. It is a ten item likert type scale with items answered on a four point scale-from strongly agrees to strongly disagree. Five of the scale items have positively worded statements and five have negatively worded ones. Rosenberg self esteem scale is considered a reliable and valid quantitative tool for self-esteem assessment. Rosenberg (1965) reported internal consistency reliability ranging from .85 to .88 for college samples. 


\section{Procedure:}

All the respondents who consented to participate in this study were briefed about the purpose of the study. Each respondents were then provided with two questionnaire (Home environment inventory, Rosenberg self esteem scale).The questionnaires were administrated individually. After establishing rapport, respondents were ensured about the confidentiality of the data and motivated to answer sincerely. The researcher confirmed whether the subject had omitted any questions.

\section{Statistical Analysis of the data:}

After collecting the data from respondents, it was scored based on the instructions given in the manual of Home environment inventory and Rosenberg self- esteem scale. SPSS ver.17.0 was used for the statistical analysis of the data. T-test was employed to examine whether there is significant difference between delinquents and normal boys in relation to their home environment and self esteem.

\section{RESULT AND DISCUSSION}

Table 1 indicates the mean, standard deviation and t-value of variable home environment and its dimensions for delinquents and non-delinquents.

\begin{tabular}{|c|c|c|c|c|c|}
\hline \multirow{2}{*}{$\begin{array}{l}\text { Home } \\
\text { environment }\end{array}$} & \multicolumn{2}{|c|}{ Non-Delinquents } & \multicolumn{2}{|c|}{ Delinquents } & \multirow[t]{2}{*}{ P-value } \\
\hline & Mean & S.D & Mean & S.D & \\
\hline Control & 26.034 & 3.908 & 20.234 & 3.839 & $5.799 * * *$ \\
\hline Protectiveness & 31.434 & 5.513 & 19.3 & 4.801 & $9.091 * * *$ \\
\hline Punishment & 30.334 & 4.482 & 18.6 & 4.091 & $10.591^{* * *}$ \\
\hline Conformity & 33.8 & 3.727 & 19 & 4.402 & $14.054 * * *$ \\
\hline Social isolation & 16.834 & 5.523 & 20.867 & 6.257 & $2.647 * *$ \\
\hline Reward & 35.8 & 3.387 & 17.267 & 4.892 & $17.061^{* * *}$ \\
\hline $\begin{array}{l}\text { Deprivation of } \\
\text { privileges }\end{array}$ & 12.4 & 5.781 & 21 & 6.198 & $5.558 * * *$ \\
\hline Nurturance & 31.634 & 4.665 & 17.167 & 5.602 & $10.869 * * *$ \\
\hline Rejection & 9.4 & 4.861 & 28.334 & 6.244 & $13.105^{* * *}$ \\
\hline Permissiveness & 23.3 & 4.427 & 20.634 & 4.759 & $2.247^{*}$ \\
\hline $\begin{array}{l}\text { Total home } \\
\text { environment }\end{array}$ & 250.967 & 15.882 & 202.4 & 22.879 & $9.551^{* * *}$ \\
\hline
\end{tabular}

$\mathrm{P}<0.001 * * *, \mathrm{P}<0.01^{* *}, \mathrm{P}<0.05^{*}$

t-test was carried out in order to compare the difference between delinquents and nondelinquents in relation to their home environment in the following dimensions-control, protectiveness, punishment, conformity, social isolation, reward, deprivation of privileges, nurturance, rejection and permissiveness. 


\section{Home Environment and Self-Esteem: Comparative Study among Delinquent and Normal Boys}

Results of t-test revealed that normal boys are experiencing significantly $(\mathrm{p}<0.001)$ high control compared to their delinquent counterparts. Mean value of control dimension for non-delinquents (26.034) are greater than delinquents (20.234). In HEI, control is defined as "autocratic atmosphere in which restrictions are imposed on children by parents in order to discipline them." The study found that monitoring plays an important role during adolescence and it reduces the chance of delinquency. The results of this study is found to be in agreement with other studies carried out by Farrington \& Loeber, 1999; Aufserr, Jekielek \& Brown 2006.

"The most crucial and pervasive of all the influences exerted in home were love and warmth imparted by parents” (Sears, Maccoby \& Levin, 1957). Like they suggest, in Home environment inventory (HEI) also nurturance is a dimension that measures the existence of unconditional physical and emotional attachment of parents with the child. In the present study also it was found that delinquents lack nurturance compared to normal boys $(\mathrm{p}<0.001)$. Mean value of nurturance for delinquents (17.167) are less compared to normal boys (31.634). Juvenile misconduct is a potential consequence when parents fail to establish emotional bonding with them (Terlouw \& JungerDas, 1992; Martens, 1992; Harada, 1995).

Protectiveness implies prevention of independent behaviour and prolongation of infantile care. The present study found that non delinquents are experiencing significantly $(\mathrm{p}<0.001)$ high level of protectiveness compared to their delinquent counterparts. Mean value of protectiveness for normal boys (31.434) are greater than delinquents (19.3).Insecure attachment can be suggested as a reason behind delinquency. Supportive parent-child relationship reduces the risk of delinquency (Dishion, Reid \& Patterson, 1988; Wells \& Rankin, 1998).

In HEI, punishment is defined as physical as well as affective punishment to avoid the occurrence of undesirable behaviour. In the present study, it was found that normal boys receive significantly $(\mathrm{p}<0.001)$ higher amount of punishment compared to their delinquent counterpart. The mean value of punishment dimension was higher for non delinquents (30.334) than delinquents (18.6). At the same time, present study also revealed that delinquents are experiencing significantly high social isolation $(\mathrm{p}<0.01)$ and deprivation of privileges $(\mathrm{p}<0.001)$ compared to normal boys for negative sanctions. The mean value of social isolation and deprivation of privileges for delinquents was found to be 20.867 and 21, which was higher than non delinquent's result $16.834 \& 12.4$ respectively. Social isolation is indicated as the use of isolation from beloved persons except family members for negative sanction. Deprivation of privileges is defined as controlling children's behaviour by depriving them or their right to seek love, respect and childcare from parents. From the study it is evident that positive discipline method (Catalano et al, 1993; Dishion, Reid \& Patterson, 1988; Kellam, Brown, Rubin \& Ensminger, 1983) reduces the rate of delinquency at the same time harsh methods such as love withdrawal increases the rate of delinquency. 


\section{Home Environment and Self-Esteem: Comparative Study among Delinquent and Normal Boys}

Conformity refers to demands to work according to parent's desires and expectations. Results of $\mathrm{t}$ test revealed that normal boys are experiencing significantly $(\mathrm{p}<0.001)$ high conformity compared to their delinquent counterpart. Mean value of conformity for normal boys (33.8) are greater than delinquents (19). When the conformity level increases, children try to work in accordance with parent's directions, commands and orders that help them to avoid negative consequences such as affiliation with negative peers and they see parents as resource person. The study also found that permissiveness was also higher among non delinquents than delinquents $(\mathrm{P}<0.05)$. Permissiveness includes provision of opportunities to child to express his views freely and act according to his desires with no interference from parents. The mean value of permissiveness for non delinquents was found to be 23.3 and for delinquents, it was 20.634.From the results we can conclude that moderation between conformity and permissiveness helped the non delinquents to avoid negative sanctions.

In HEI, reward is defined as "Material as well as symbolic rewards to strengthen or increases the probability of desired behaviour."The study found that non delinquents are receiving higher amounts of rewards than delinquents $(\mathrm{p}<0.001)$. Mean value of reward dimensions for non delinquents (35.8) are higher than delinquents (17.267). Reward motivates the children to repeat desirable behaviours and avoid undesirable behaviours. Social learning theory suggests that children's behaviour depends on parental rewards and punishments and on the models behaviour that parents repeat (Farrington \& Loebor, 1999).

Rejection implies conditional love recognizing that the child has no right as a person, no right to express his feelings, no right to uniqueness and no right to become an autonomous individual. In the present study, it was found that delinquents are experiencing significantly $(\mathrm{p}<0.001)$ high rejection compared to normal boys. The mean value of rejection for delinquents was found to be 28.334 and for normal boys, it was 9.4. Rejection from parents destroys conscience of the child and he may behave in antisocial manner. (Brook, Whiteman, Gordon, Brook \& Cohen, 1990; Cole \& Zahn-Waxler, 1992)

From the results, it's evident that there is a significant difference $(\mathrm{p}<0.001)$ between delinquents and non delinquents in relation to their home environment. Home environment is the psycho social climate of child, i.e., measure of the quality and quantity of the cognitive, emotional and emotional support that has been available to the child. The mean value of total home environment for normal boys (250.967) is greater than delinquents (202.4). Lack of care, inconsistent discipline methods, and negligence of basic needs, wrong company and other abuse may turn the child into a delinquent. The result of this study found to be in agreement with Klein \& Forehand, 1997 and LeBlanc, 1992. 
Home Environment and Self-Esteem: Comparative Study among Delinquent and Normal Boys

Table 2: Mean , standard deviation and t-value of variable self esteem for delinquents and normal boys.

\begin{tabular}{|l|l|c|l|l|l|}
\hline \multirow{3}{*}{ Variable } & \multicolumn{2}{|l|}{$\begin{array}{l}\text { Delinquent } \\
\text { S n=30 }\end{array}$} & \multicolumn{2}{|l|}{$\begin{array}{l}\text { Non delinquents } \\
\mathbf{n = 3 0}\end{array}$} & \multirow{2}{*}{ t-value } \\
\cline { 2 - 5 } & Mean & S D & Mean & S D & \\
\hline Self esteem & 202.4 & 22.879 & 250.967 & 15.882 & $9.551^{* * *}$ \\
\hline $\mathrm{P}<0.001 * * *$ & & & & \\
\hline
\end{tabular}

Table 2 indicates the mean, standard deviation and t-value of variable self esteem for delinquents and normal boys. Results of $\mathrm{t}$ test revealed that delinquents are experiencing significantly $(p<0.001)$ low level of self esteem compared to normal boys. The mean value of self esteem for normal boys (23) is greater than delinquents (16.1). Studies found that lack in self-esteem foster delinquency and delinquency may increase the self-esteem (Kelley, 1978).

\section{CONCLUSION}

The present study was aimed to compare delinquents and non delinquents in relation to their home environment and self esteem. From the results it was found that there is significant difference between home environment and self esteem of delinquents and non delinquents. Parental control, Protectiveness, punishment, conformity, reward, nurturance, and permissiveness play an important and effective role in the developmental growth of personality as well as social behaviour of the non delinquents. It was also found that delinquents are experiencing significantly low level of self esteem compared to non delinquents. Thus, from the above findings it can be concluded that Home environment and low self esteem are important indicators of delinquent behaviour and important variables which clearly differentiates between delinquent and non delinquent boys. In view of the findings it is worth to suggest that family counselling will be an effective way to guide the public to the important of healthy family environment, for the personality as well as social development of the child.

\section{Acknowledgments}

The author appreciates all those who participated in the study and helped to facilitate the research process.

\section{Conflict of Interests}

The author declared no conflict of interests.

\section{REFERENCE}

Aufseeser, D., Jekielek, S., \& Brown, B. (2006).The Family Environment and Adolescent WellBeing: Exposure to Positive and Negative Family Influences. Washington, D.C.: Child Trends; and San Francisco, CA: National Adolescent Health Information Center, University of California, And San Francisco. 


\section{Home Environment and Self-Esteem: Comparative Study among Delinquent and Normal Boys}

Barber, B. K. (1996). Parental psychological control: Revisiting a neglected construct. Child Development, 67(6), 3296-3319

Brook, J. S., Whiteman, M., Gordon, A. S., Brook, D.W., \& Cohen, P. (1990).The psychosocial etiology of adolescent drug use: A family interactional approach. Genetic, Social \& General Psychology Monographs, 116(2).

Catalano, R. F., Hawkins, J. D., Krenz, C., Gillmore, M., Morrison, D., Wells, E., \& Abbot, R. (1993). Using research to guide culturally appropriated drug abuse prevention. Journal Consulting and Clinical Psychology 61: 804-811.

Cole, P. M., \& Zahn-Waxler, C. (1992).Emotional dysregulation in disruptive behaviour disorders. In D. Cicchetti \& S.L. Toth (Eds.), Rochester Symposium on Developmental Psychopathology, Vol. 4: Developmental Perspectives on Depression (pp. 173-209). Rochester, NY: University of Rochester Press

Dishion, T. J., Reid, J. B., \& Patterson, G.R. (1988).Empirical guidelines for a family intervention for adolescent drug use.Journal of Chemical Dependency Treatment 1: 189224

Fischer, D. G. (1983).Parental supervision and delinquency. Perceptual and Motor Skills, 56(2), 635-640.

Farrington, D. P., \&Loeber, R. (1999). Transatlantic replicability of risk factors in the development of delinquency. In P. Cohen, C. Slomkowski, \& L. N. Robins (Eds.), Historical and geographical influences on psychopathology (pp. 299-329). Mahwah, NJ: Erlbaum.

Harada Y 1995. Adjustment to school, life course transitions and changes in delinquent behaviour in Japan. In: Z Blau, J Hagan (Eds): Current Perspectives on aging and the life cycle: Delinquency and Disrepute in the Life Course, Greenwich, NY: JAI Press, pp. 3560.

Kellam, S. G.; Brown, C. H.; Rubin, B. R.; \&Ensminger, M. E. (1983).Paths leading to teenage psychiatric symptoms and substance use: Developmental epidemiological studies in Woodlawn. In S.B. Guze; F.J. Earls; \& J.E. Barrett (Eds.) Childhood Psychopathology and Development: 17-51. New York, NY: Raven Press.

Kelley T M (1978), “Changes in self esteem among predelinquent youths in voluntary counselling relationships”. Juvenile and family court journal 29.

Klein, K \& Forehand, R (1997).Delinquency during the transition to early adulthood: Family and parenting predictors from early .Adolescence.32:61-81.

LeBlanc, M (1992) Family dynamics, adolescent delinquency, and adult criminality. Psychiatry, 55(4)336-353.

Martens P L 1992.Famij, Uppvaxt Och Brott (Family, Environment, and Delinquency). Stockholm, Sweden: Brottsforebygganderadet.

Sears, R., Maccoby, E., and Levin, H., (1957). Patterns of child rearing, Row Peterson,

Evanston, III.Smith, C.A., and Sterns' (1997).Delinquency and antisocial behaviour. A review of family processes and intervention research. Social service review, 71,382-420. 
Home Environment and Self-Esteem: Comparative Study among Delinquent and Normal Boys

Terlouw G, Junger-Tas J 1992. The international self-report delinquency study: Design and first results of the Dutch survey. Paper presented at the 44th annual meeting of the American society of criminology, New Orleans, L A. From http://family.jrank.org/pages/1008 Juvenile Delinquency Conclusion.html $>$ Juvenile Delinquency-Conclusion</a $>$ (Retrieved June 17, 2015).

Wells, L. \& Rankin, J. (1998).Families and delinquency: A meta- analysis of the impact of broken homes. social problems, 38, 71-93.

How to cite this article: D Varghese, S Menon (2016), Home Environment and Self-Esteem: Comparative Study among Delinquent and Normal Boys, International Journal of Indian Psychology, Volume 3, Issue 4, No. 77, ISSN:2348-5396 (e), ISSN:2349-3429 (p), DIP:18.01.062/20160304, ISBN: 978-1-365-51571-2 